\title{
The European Perspective of the Western Balkan- The Case of Albania, Kosovo and Macedonia
}

\author{
Miranda Sabriu, PhD \\ Assistant at South East European University \\ Public Administration and Political Sciences Faculty, Ilindenska nn, Tetovo-Macedonia \\ E-mail: m.sabriu@seeu.edu.mk
}

DOI: $\quad 10.6007 /$ IJARBSS/v3-i12/448 URL: http://dx.doi.org/10.6007/IJARBSS/v3-i12/448

\begin{abstract}
The integration of the Western Balkan countries with provides new members with many benefits in political as well as in economical part. The liberalization of inter-regional trade will help countries in the region to improve their mutual cooperation economically and politically. The membership in the European Union would motivate all countries in the western Balkans to improve and correct the existing problems and opened issues, and to actively undertake and participate for a better future of the Balkans. Before we start thinking of the subject of this topic, there has to be done a précising of the criteria, according to which we will organize the countries who are waiting for their "biggest European Day", the final accession in the European Union. There are at least two possible approaches for their "classification". First of all, according to the size of the territory and population, and according to the "weight" of the problems facing each of them on the road to Brussels.
\end{abstract}

Keywords: Western Balkans, European integration, stability, security

\section{INTRODUCTION}

The fragility of the Balkans is one of the main objectives of the European Union agenda. The example of the European Union is often pointed out as an undertaking that maintains peace among its member states. From the perspective of the past experiences that countries that agreed to enter a certain modality of integration, the Western Balkans would benefit a lot in increasing cooperation among its members in many areas. The Western Balkans refers to the region of Southeastern European countries involved in the EU Stabilization and Association Process: Albania, Bosnia and Herzegovina, Croatia, Serbia and Montenegro and the Former Yugoslav Republic of Macedonia.

The Western Balkans in the last decade of the twentieth century has gone through many problems in the political plan as well as in the economic plan. Concerning the political problems, these countries were driven by many ethnic conflicts as the main problem, starting with the dissolution of Ex-Yugoslavia and other social problems, like, underdeveloped civil societies, lack of the rule of law and destroyed economic systems. The Balkans with its favorable geographic features and economic opportunities has attracted people since the 
ancient times due to geopolitical situation. It has always been a ground for co-existence of different culture, religions and peoples over a small territory, making the Western Balkans as a multicultural and multiethnic conflict region.

The fact of integration into European Union would save the Balkan region from further interethnic conflicts. The issues like, border issues, ethno - religious conflicts, cultural and historical tensions and legal disputes will be solved when the western Balkans countries will join the EU family.

All the Western Balkan countries have become either candidate countries or potential candidate countries but the whole Balkan countries becoming part of EU is far from reality. The accession process requires both efforts from the candidate countries and the willingness of EU members and institutions to accept newcomers in their EU family integration and enlargement.

\section{METHODOLOGY}

This paper concentrates on secondary sources of research regarding the political integration of countries. The paper analyzes the secondary data, previous research conducted on the field of integration, and what integration first occurs, whether the political integration precedes the economical integrations or they complement each other. The main focus of the paper is the idea behind the integration of western Balkans.

The readings chosen for this paper were sourced from leading authors in the field, as well textbooks and electronic academic sources. Therefore, in order to understand the need for integration of the Balkans states, secondary information will be collected, and the data will be compared and analyzed. Finally, the conclusions will be submitted.

\subsection{Research Questions}

The purpose of this research is to find an answer to the following research questions about the integrations of the western Balkan countries, and the importance of political and economical integration of the Balkan region itself. Therefore, the paper will focus mainly on answering the following research questions:

1. Why are the opportunities and challenges of the western Balkans countries?

2. What are the advantages of forming regional and worldwide blocks of integration?

\section{LITERATURE REVIEW}

\subsection{Albania}

If Croatia is excluded (which will be discussed later), Albania is the country with the biggest chances to be the first one to finish the process of accession in the EU.

There are two main arguments in defense of this conclusion. The first is the powerful support of the United States. It is so obvious that hardly needs a detailed explanation. Therefore, some experts see in Albania indisputable "favorite" of Washington in the Balkans.

The second argument is the successful finalization - in 2009, the Euro-Atlantic integration of Albania. Related to this, she received resounding support not only from the U.S., but on the other hand - an influential member of NATO - Turkey. Thus, Albania became one of the countries of the Western Balkans, which since 2009 has been a member of NATO (Croatia is the other state, admitted to the North Atlantic Alliance in the same year). While on this issue, we 
can add a further analysis made by the President of Albania Alfred Mojsiu related to Albania's relations with NATO and the aspiration of the country's membership in the Alliance.

Albania occupies a special place in NATO's relations with the countries of former Eastern block, writes at the outset of its analysis the head of the Albanian state. This is due to the fact that the first of the former communist countries stated desire to join the pact - in December 1992. Four months later, NATO Secretary General Manfred Werner made official visit to Tirana, which opened a new chapter in relations between my country and the most successful treaty of modern times. In early 1994, Albania approved the concept Partnership for Peace and the signing of the framework document on 23 February of that year she was listed within the first countries that joined the initiative.

Moisiu states that before becoming president, he was Minister of Defense and Chairman of the Albanian Atlantic Association (in this regard he looks like Solomon Passy, who was also Minister /not of defense, but of foreign affairs and President of the Atlantic Club in Bulgaria) and he claims "NATO integration has been and remains a key priority for Albania". A. Moisiu (2004) is convinced that "both the government and the Albanian general public consider the EuroAtlantic integration vitally important to the country and its future." We believe that Albania deserves membership in NATO, not just because of the strong connection of Albanians with the Alliance, but because our country for many years now acts as a real member of NATO. Operations in Bosnia and Herzegovina, Kosovo and the former Yugoslav Republic of Macedonia led by NATO and our participation in SFOR and ISAF intensified feelings of sympathy and support to NATO, U.S. and Euro-Atlantic values among wide circles of the population. Every citizen, politician and president has an idea, a project or a goal in his life, which wants to fight for. My dream is to see the integration of my country in NATO. This dream is shared by the vast majority of my countrymen and unanimously goal of tomorrow's generation that is currently growing up. I hope and believe that with our joint efforts that dream will one day become reality; the president finishes his analysis here (Retrived from: Albanian dream. http://www.nato.int/docu/revive/2004/issue/Bulgarian/special.html).

However you should not ignore the fact that Albania welcomes first years of second decade of the third millennium with not - so - clear vision of its "European (KM - B.M.N.) future. "Underwater stones " that Tirana has to overcome, can - although quite figuratively, be reduced to two main groups: internal and external.

Let us start with the internal. Despite the factors analyzed earlier, there are still some ambiguous and not totally clear declarations of some politicians in Tirana. We already cited the declaration of Sali Berisha - as a president of Albania at that time, who admits that there is such an option of "unification of all Albanians". But, he is convinced that there is lack of "unification potential" nowadays. This conviction is not shared by other foreign politicians and analysts, especially when it comes to "tomorrow" not to "today". Even more, these type of declarations cause more concerns rather than certainty about the future of the region and the whole continent also.

These fears await another declaration of this type, by the already mentioned Alfred Moisiu, in 2005, during a visit in Russia, in 2005, while being asked the question: "Do you find justified the declarations that Tirana is preparing for the Great Albania which would include all the territories where Albanians live?," he gives this answer: Albania is one of the countries in the Balkan region, known for its history full of conflicts and bloody wars. Albania has never entered 
a war, hasn't been opposed by neighboring countries and has not allowed the realization of extremist and nationalist plans. We know that we cannot move forward as a result of war, but in friendship and cooperation. We are interested in the Balkans to be stable, democratic, developed and integrated, where all inhabitants of the region have rights, fixed in international conventions. Albanians are scattered in 4-5 countries in the region and that has a strong impact on our interest Balkans to exist in peace and harmony. Albania's always had a positive impact on the deepening of democratic processes in countries where Albanians live, giving a significant and valuable contribution to the strengthening of peace and stability in the region.

Albanian state and Albanians in the region tend not to create a common state for all Albanians or the demolition of neighboring countries, where Albanians are an essential constituent element. We strive towards our regional integration in Euro-Atlantic structures, to the free exchange of ideas, movement of people, goods, to intensive cooperation with all neighbors and to the strengthening of peace and security. It would turn the Albanian factor in real and very important factor of stability and the preservation of peace in the region. „(Interview of Albanian President Alfred Moisiu (Retrived from http://www.rian.ru./interview).

In this case, it is not that important the contents within the ideas for "Great Albania" or "Natural Albania". More important is the fear - of the neighboring countries, of the European Union as a whole, and of its members separately. That's especially important when it comes to te member countries, like Germany and France, which can form, model or impose public opinion with negative feelings and even prejudices. And not just within its own borders, and in much broader scale. Therefore Tirana should make every effort to persuade the European public and European institutions that has no territorial claims against other states, it is hard and uncompromisingly committed to developing and enriching mutual cooperation with all countries in the region - both bilateral and multilateral plan.

No less important are external factors. In the first place, and there should be specified the requirement and practice in the EU while making important decisions (full European integration of Albania falls in this group) to be respected the principle consensus. The principle is clear enough and there is hardly need of commenting the fact that even a single Member State is able to block the development of integration processes. Now the number of members of the Union is 27 , but in a few months it is expected the official accession of Croatia, which will make the coordination of views and consensus even more difficult.

The possibilities that Balkan neighbors can stop the euro integration of Albania should not be left aside. Greece comes first, which won't even doubt on putting its conditions related to the up-mentioned open and contentious issues. It is logically to think that Greece will have the support of Cyprus, and of Italy maybe, which has its difficulties mainly with the massive immigration of Albanians in the Apennine Peninsula.

The image of all this gets even more complicated if Albania lags behind its neighbors - Serbia and Macedonia, in the issue of Euro Integration. In that case there would be no doubt that Belgrade and Skopje will try to extract maximum dividends of their privileged situation and oppose European Integration of Albania. Bulgaria would be the only country here interested in the integration of Albania in EU. Kosovo is out of this, because of two reasons at least: 1. because the relations between Kosovo and Albania are more than neighborly. Those relations are between compatriots, although in two different countries; 2 . at the moment there is no 
even hypothetical possibility Kosovo to exceed any other country in the race of membership in the EU, even Albania.

We already mentioned that on the $10^{\text {th }}$ of October 2012, few days before the end of this research, the European Commission adopted the annual progress reports of the Western Balkan countries on their path towards membership of the European Union, as well as the strategy for the enlargement policy of the Union in 2013. Now Albania was one of the highest estimates of the Western Balkans - along with Macedonia and Montenegro. European Commission recommended the country to get candidate status for EU membership. The Commission's decision is justified by the recognition that Albania has made good progress in meeting the political criteria for EU membership, in particular the renewed political dialogue between the main political parties in the country. However this recommendation was accompanied by certain conditions that Tirana must meet before they complete the accession process. Firstly, it is the need of completing reforms in key areas, such as the judiciary and public administration.

A serious problem that Albania still fails to resolve is the fight against corruption and organized crime. The Albanian authorities are expected to do serious work, which will guarantee rule of law and respect for fundamental rights. Very important test of the maturity of the political elite and Albania's progress on the road to full membership in the EU will be parliamentary elections in 2013 - a traditional ordeal of the political class in Albania since the beginning of transition. Simultaneously normal maintenance of these elections will be an important prerequisite for the country to get a recommendation to start negotiations for EU membership.

Regardless of these notes however commentators and analysts are almost unanimous forecasting that Albania will be the second country (the first will be Montenegro), which will monitor Croatia.

\subsection{Kosovo}

It's European and Euro-Atlantic perspective is difficult to comment, analyze and foresee. The reasons for this are complex. If however there is an attempt to systematize, the first thing to be mentioned is the status of Kosovo. The youngest Balkan state sees itself as an independent and sovereign. Such is the position of the majority of Member States of the European Union and NATO, who quickly recognized the independence of Kosovo. At the same time, however, we should not neglect the fact that the five member states of the EU and NATO (Greece, Spain, Cyprus, Romania and Slovakia) refuse to recognize Kosovo as an independent state. Similar is the position of the 102 UN member states (out of 193) which are currently staying away from recognizing Kosovo's independence. It is Indicative that among these two are the countries permanent members of the Security Council UN: People's Republic of China and the Russian Federation. Without minimizing the role of member states of the UN, it must be noted that in this case the most important is the resistance against Kosovo independence by five member states of the EU and NATO, because each of them can veto Kosovo's application for membership in both unions. And they all have their reasons and their fears that may be followed the fate of Serbia, despite the attitude of the most important international factors that Kosovo is a unique case and cannot be used as precedent. 
The second reason is the economical instability of Kosovo. Regardless of immense help received from the Albanian diaspora in the U.S. and other international sponsors and donors, economy of the youngest Balkan country is in an extremely difficult situation. Autonomous Province of Kosovo was most disadvantaged region in the former Yugoslavia, despite the help received from developed republics through a special fund to help backward regions in the federation, created for this purpose. Even after independence, Kosovo's economy continues to be one of the most disadvantaged economies in Europe. In this situation categorically cannot be expected that the leading economies in the EU (UK, Germany, France), who also face very serious challenges, will be keen to show willingness to burden its taxpayers with additional financial weights to support the economy of Kosovo.

Third reason is the state of the judiciary, to which the EU is particularly picky. Without exaggeration we can say that the Kosovo judiciary in some of its segments is archaic. In Kosovo (as in Albania and in some regions of Macedonia and Montenegro, where Albanians live) still it is judged according to the laws of customary rights under Canon of Leke Dukagjini. Implementation of such a blood feud still continue, which thus disavow the decisions of legitimate but an inefficient judicial system. Attempts by some factors (in the first place - the Catholic Church) for this practice to be removed or at least to be limited at its maximum it's not giving serious results.

EU pays attention to the organized crime, which is often compared to the Russian mafia, considered the strongest in Europe. This is a particularly dangerous form of organized crime such as human trafficking and drug smuggling.

Finally - current status and future development of bilateral relations in Kosovo with its immediate neighbors. The greatest danger lies in the unwillingness of Serbia to recognize Kosovo's independence, although now somewhat hypothetical, does not exclude complications in relations of Kosovo with Macedonia and Montenegro. Differently said, Kosovo is a particular problem or issue for itself. It greatly affects Serbia, which continues to consider the province as part of its territory. For the situation in Kosovo more or less is also shown interest by several countries in the region: Albania, Montenegro, Greece and (perhaps) Bulgaria. The present and future of the young Balkan state (in particular aspects of security) is also a problem of the EU, and therefore of Europe as a whole).

The less mentioned last Balkan diplomatic "shuttle" of U.S. Secretary of State Hillary Clinton, accompanied by a senior representative of the EU foreign policy chief Catherine Ashton fits in this context. Even the specific date of the visit in the Western Balkans was not according to the time of filing the Commented report of the European Commission, it made many of the objectives outlined in the report to be achieved. Specifically when it comes to Kosovo which is the most important message of Washington and Brussels, the statement of $\mathrm{H}$. Clinton and the softer one from Eshton was: "Kosovo's independence is undeniable." "We are opposed to any talk of changing the boundaries or re-imposing the issue of Kosovo's independence. For it cannot be discussed, "concluded Clinton. At the same time she warned that the continuation of the dialogue with Belgrade and the normalization of relations with Serbia will be crucial to economic and social progress in Kosovo.

The following emotional statement of Clinton sounded very strong: " For me, my family and my American citizens (the independence of Kosovo -M.N.B) is more than an exterior political issue. This is a personal matter." It is clear that it's not about a spontaneous emotional outburst, but a 
well-planned step which would remind of the decisive role played by the husband of Hillary Clinton, the president of USA, for the victory of Albanians in Kosovo.(Clinton, $\mathrm{H}, 2012$ )

When all these factors are taken into account it's more than accurate that is too early to talk about the European integration of Kosovo.

\subsection{Macedonia}

The former Yugoslav Republic of Macedonia officially got the status of candidate country for EU membership on 17.12.2005. It was expected to end the discussion over its security and even of its existence as a state. These forecasts were justified but not completely. This applies primarily to the situation of ethnic relations. Macedonia was among the countries that had a reason to be satisfied by the European Commission in October 2012. The European Commission again (for the fourth time in a row) recommended starting negotiations with the Republic of Macedonia for EU membership. In Skopje the recommendation was received with mixed feelings, which found expression in the appropriate rhetoric. Governmental sources have expressed great optimism that this time the European Parliament will listen the opinion of the Commission and will fix an exact date for the start of negotiations. It is often suggested that it is possible to happen in early December 2012. In support of this prediction it is provided a solution for Montenegro for similar case studies, which will be discussed later. The opposition by all rights tried to rule the debates and pinpoint barriers that can be interposed before Skopje. Debates continue as we are completing the research, no real prospects to mutual acceptable opinion, even less - just a general acceptable solution.

At the same time the European Commission has declared its readiness to immediately present a plan for the negotiations framework. The requirements that Macedonia should meet were immediately listed. This meant the specification of the exact date for the start of accession negotiations. Again as a major obstacle is the already chronic dispute with Greece over the country's name. Compared with previous reports, it now speaks of "the need of resolving the dispute at an early stage of negotiations". This is really a news, and very important, because it is understandable why even in these days Skopje's keynote is right on it. Even media are more critical than supportive to the Government and personally to Prime Minister Nikola Gruevski, rushed to publish the opinion of Franco Frattini, introduced as "a former head of Italian diplomacy, former European commissioner for justice and internal affairs and possible future Secretary General of NATO that "all EU member states" should work to achieve a solution to the country's name, "to open the door (of the EU - M.N.B.) and to give a date for the start of accession negotiations. Franco Frattini hoped EU succeeds to unblock this difficult situation "because" it's not only in the interest of Skopje, but of the EU also. (Utrinski Vesnik, October, 2012 ).

One of the most suitable comment for Macedonia is stated by already mentioned Slovenian MEP Tanja Fajon. She believes that if obstacles are not removed, "the further isolation of the country obviously will pave the way for even more nationalist and populist rhetoric. According to T. Faion it's the final time to begin negotiations with the EU for accession and to find a quick solution for the open bilateral issues. Any delay of the beginning of negotiations is bad for both Macedonia and the region in general, and the European Union "(Utrinski Vesnik, October, 2012). 
Again, in this context are given statements of unnamed senior officials of the European Commission, that if the EU Council adopts the recommendation (EC - M.N.B.) to Macedonia, our country (Macedonia - M.N.B .) could begin negotiations at the date of the decision, when Summit of the highest level will be held, which means the December 13th or 14th. This forecast is based on the precedent already mentioned in Montenegro (Utrinski Vesnik, October, 2012). Both cases, however have almost no common ground, because the forecast looks too optimistic and even completely unfounded.

Several European politicians and experts, and authoritative world media, assess quite differently the current situation in Macedonia and recommendations in the report of the European Commission. EU Enlargement Commissioner Stefan Fule through its spokesman Peter Stano made it clear that the EC does not want to reveal what will be the framework for solving the name issue at an early stage of negotiations for Macedonia's membership in the EU . "Let's wait for the answer of the summit of the highest level of member states, and then discuss technical details to resolve the dispute" (with Greece - M.N.B.), declared Peter Stano (Utrinski Vesnik, October, 2012).

While looking for alternative opinions for the problem we see here, we found (accidentally to somewhere) an interesting publication (Zahariev, n.d). The author Zahari Zahairev is obviously a young man, but that doesn't stop him from writing in a not so standard form and come to interesting conclusions. It can be said that exactly that fact helped him in a great way to fulfill the task that he set for himself. Most surely he was helped by the chance to take part in the meeting where the report for progress of FYROM was shown. That's why we will allow citing more in details some of his opinions.

When considering the accession of the former Yugoslav Republic of Macedonia (FYROM) in the EU, we must consider it along with Albania and Kosovo. Among the three, the key relationship is the ethnic and religious composition of the population. That was the reason that Kosovo was separated, while in FYROM there's an increase in inter-ethnic conflicts, which in places reached even to armed conflicts like those in Tetovo and Kumanovo. Here THE EU MUST SEEK PRAGMATIC APPROACH that can help to deal with problems and not leave FYROM rely solely on their own forces, because the delay of accession negotiations at the time actually remove on the European horizons of the country. "

Furthermore, Z. Zahariev says that while considering the progress report of FYROM for joining the EU, the Euro MP were divided for the kind of progress the country has achieved and how should the access of solving the problems on the way to EU be.

According to Bulgarian MEP Dr. Andrew Kovacev of the European People's Party for the stability of the country is important to guarantee equal rights and responsibilities for all citizens and an opportunity all ethnic groups to participate in political and economic life of the country. He claims that Macedonia is one of the few countries in Central and Eastern Europe, which has not stopped the communist ideology, in this case the building of identity at the expense of the culture and history of the neighboring countries. This practice creates dividing lines within Macedonian society and affects good neighborly relations.

FYROM has always been the key towards the processes in the Balkans, and even not so close to full membership in the EU, its behavior as a subject of international relations and European issues causes exceptional interest. Another MEP from Bulgaria - Kristian Vigenin, expresses his opinion that "the development of good neighborly relations and the resolution of contentious 
bilateral issues in the spirit of European values is an indicator of progress towards EU membership, because enlargement process should integrate partners, not unsolved problems "(notes of W. Zacharias, n.d.).

"For FYROM is important to complete as soon as possible the process of state creation and to find a compromising solution for its name, to link its history with the ones of neighboring countries and start to apply the policy of good neighborliness and cohesion. It will allow it to become a member of NATO, which will guarantee its security, internal stability and democracy and then will be ready to make the last few steps to join the only European space "( notes of W. Zacharias, n.d.).

So logically we arrived to a problem, which for several months is causing wide discussion relations between Macedonia and Bulgaria. Of them are now interested not only the political class but the population of both countries too. It affects both the EU and NATO as a whole. The Bulgarian-Macedonian relations cause tension, which was typical for other periods. Again we are witnesses of the accusations from both sides for "looting of historical heritage", the "territorial pretensions of Bulgaria", and so on. In this case it is hardly essential to trace who was the first that began this irrational dispute. Much more important is to find a reasonable solution and approaches to normalize the situation. There can be hardly doubt that much more benefit from the development of similar things would have Macedonia, because eventual complication of the communication between Skopje and Sofia can further slow down the European and Euro-Atlantic integration of the country.

At first sight it seems that currently only Sofia profits from this dispute. It is still difficult to assess how things will look in the medium and long term perspective. Some statements and declarations of the Minister of Foreign Affairs in the government of Boyko Borisov - Nikolay Mladenov and especially the President of the Republic of Bulgaria Rosen Plevneliev, help the greatest Macedonian nationalists by giving additional arguments for the use of warlike rhetoric. In the notes about Macedonian actions and inaction on the road to Brussels we used an interesting analysis of a young Bulgarian author - Zachary Zacharias. We will finish the analysis of a Macedonian author, but not young and a man of solid age, a former diplomat, with a sharp pen. Behind the seemingly light tone of his publication there are hidden conclusions which will certainly cause a lot of interest among readers, and not just in our region (Politics, October, 2012). The author explains that "it would be useful" to remind "the position of the EU, respectively to its most influential members in the period of independence of Macedonia until 1995 (established diplomatic relations with Brussels), then in the run-up to receiving the status of candidate (2005) and last - until the first recommendation of the European Council on setting a date for negotiations to today ... "At that time" the democratic contribution of the EU institutions is obvious. Analyzing the same period, you can see our responses to the open questions by the European Commission, specifically highlighted after receiving the candidate status. "

„Waiting for the summit in December" the author once again explains the "clear positions" and writes:

„1. European Union in our region plays the role of educator. Some states were previously penalized with the loss of territory, some - with the loss of sovereignty with virtual territorial integrity, some - with stronger elements of confederation (like a constant back 
position). Some semi-recognized states without territorial integrity, which in its latest report, the $\mathrm{EC}$ insists on being respected.

2. Europe is an old lady. Experienced. Resourceful (this word has the meaning and "cunning" - M.N.B.). Loves suffering, but not those who suffer. Living well from new members. Quit the eastward expansion, further from the boundaries of Poland. Slovenia is accepted in the EU not as a state of the Western Balkans. Croatia fought for the same status, but failed. It's not yet known if it will be the deadline for admission to the EU (July 2013). The case is being repeated with Bulgaria and Romania.

3. When in the region remained only Macedonia, Montenegro, Albania and Serbia, the EU was oriented towards harmonization of positions, emphasized Kosovo's need to reach its neighbors. Great progress is the removal of supervision od independence (of Kosovo M.N.B.). Montenegro was out of this group. The biggest problem is Serbia, which followed the policy "Both the EU and Kosovo."Resolution 1244 is key of the Security Council of the UN. It should be finally canceled. However, it is not easy. Serbia has friends in the Security Council of UN (author means China and Russia - M.N.B). Daytonian Bosnia is more reminiscent of Bosnia since the chronicles of Ivo Andric. Albania and Montenegro are sure, especially the first.

4. EU shouldn't expand more. It has problems of its own. Inside EU there are three parallel "Europe", each one with its arguments (the word "card" is used by the author - M.N.B). For future expansion of the EU, crucial is the budget from 2014 to 2020, and the "key " is held by UK.

5. There we are. After Turkey, we are with the longest term of candidate, with the possibility of a recommendation to the European Council to start negotiations. If we don't get such a recommendation, it gets bad. Problem needs to be resolved. But that doesn't concern the Macedonian diplomacy. It's a decor. EU cares of it. It has its reasons. It doesn't know. It does not want more turbulence especially when it is not necessary. After "sweets" called "negotiations", came the latest proposal in the phrase "parallel negotiations and resolving the name issue." The Old Testament that the problem should be solved is not missing at this time in the early stage of negotiations with the European Commission.

The Brussel's diplomats well compiled the calendar of events. Chancellor Merkel in Athens, a letter from the Greek Minister Avramapulos to our Poposki, after that - a Project of the Memorandum of Understanding (the title is prepared in accordance with Greek priority and determines the place, manner and key documents for solution), which is not easy to answer. But there must be answers. Otherwise we lose pace and patience of the international factor.

6. The European Council reacted rationally. By saving Greece started the stopping of frightening collapse of some European Countries which were not accepted in accordance with the economic criteria. Greece saw that and started a new diplomatic initiative, after the success of the agenda of Thessaloniki (2003). It is about the Memorandum, a diplomatic document which firstly means "initiative" and not always prejudice sincere interest in formal diplomatic floccules (general stories that are used to cover up the truth; empty phrase - if you want, Floskei - Gjerme., BM - M . n.d), which can't be dropped, and they force the opposite to answer. If it's quiet, the aim is achieved. Memorandum is skillfully made. It can't be rated negatively from the unengaged countries. Our response should exceed their wisdom ... The problem is whether we have this diplomatic quality. Especially important is the last sentence of the memorandum, which might indicate that it is made in consultation with at 
least one state, a neighbor of Macedonia (KM - M.N.B. author probably makes allusion to Bulgaria).

7. Well formulated is the term - "early stage". European diplomats here say that it is better the name issue to be be solved as early as possible, but reduce the period of the early stage. Under the condition the negotiations to begin in the first half of 2013, the early phase arises in practically in 2014, when the EU will be chaired from Greece. In that way it can be put additional pressure on the Macedonian government and Macedonian diplomacy. Macedonia is on the move.

8. In the tactics of bilateral and multilateral engagement of other countries the Greeks are in advantage, especially in the bilateral plan. With a multilateral solution of the problem in New York there are many risks. Macedonia is not prepared to undertake them. It should be waited for the election of new administration in the US.

9. Macedonian position regarding the EU accession differs from Serbia. Each parallel is wrong and leads to erroneous conclusions, especially the patriotic character. The Serbian position is still more complicated, it is primarily political. The formal lack of condition, for Serbia to recognize Kosovo and at the same time insisting to take account of the its (Kosovo - M.N.B.) territorial integrity is just a calculated maneuver to Brussels. Belgrade's response won't delay too much.

10. It is indisputable that there is progress in the integration of Macedonia into the EU. But there is no final result. EU stimulates the country in the last 6 years. Now there is an opportunity with the formula of so-called early stage to resolve the name issue to put Macedonia before the last exam for EU integration. "Macedonian diplomacy ... needs to wake up. "

\section{CONCLUSION}

In this paper was made an attempt to analyze the present and predicted (if possible) future of the Western Balkans as a whole and the countries that form it (Albania, Kosovo, and Macedonia,). By definition the future is associated with their European and Euro-Atlantic prospects, with their full membership in the Organization of the North - Atlantic Treaty and the European Union. This definition was formulated and launched in the late 80s and early 90s of last century like no alternative. Relatively quickly and easily Bulgaria and Romania were admitted to NATO (in 2004) and the EU (in 2007).

At the end of the first decade of the twenty-first century, practice once again is not in line with theoretical constructs. The process of Euro-Atlantic integration "stuck" when the agenda came with the question of admission of other countries in the Western Balkans. Their Euro-Atlantic perspective clearly complicated it. It became clear that Bosnia and Herzegovina has virtually no chance of success, until it solves the extremely complicated internal problems: territorial (presence of two confronted entities), ethnic (constant tension between Bosnians, Serbs and Croats), economic, social. Currently the country is not able to deal with any of them (even having sincere desire) despite strong pressure from the world's most influential factors, firstly most of the United States. It should be taken into account the fact that Bosnia and Herzegovina is a protectorate, causing additional complications, including formal and legal. 
Admission of Kosovo in NATO currently is not officially discussed because of the unstable internal situation and foreign policy position for the youngest Balkan state. The first case concerns the economic, social, ethnic problems, and problems in safety, and in the second - the international recognition of Kosovo and its reception in the world and relevant international organizations, especially the UN. It should be added the fact that Kosovo continues to be a protectorate with all consequences arising from it.

The barrier which Greece put twice before expecting Macedonia to receive an invitation for membership in the North - Atlantic Alliance, currently seems insurmountable. The main reason is the requirement of Athens, Skopje to abandon the use of "the name Macedonia." Skopje evaluates this claim as "brutal interference in the internal affairs of a sovereign state" and "absolutely unacceptable."

Macedonia's Euro-Atlantic perspective is going away because of a warning from Bulgaria, explicitly expressed in 2012, that the country will not be admitted into NATO and the EU, if it doesn't stop anti-Bulgarian rhetoric and change of attitude towards the citizens of the country with Bulgarian self-awareness.

These arguments for Euro-Atlantic fate of the Western Balkans are totally valid of their European perspective. The current practice (without being officially formulated and argued) confirms that accession to the European Union is preceded by full membership in the Organization of the North Atlantic Treaty. Currently there are no serious indications that this practice will be changed. So here are just some added details.

First we will pay attention to existing and still open issues: between Greece and Macedonia, between Macedonia and Albania, between Bulgaria and Macedonia. Strongest remaining problems are between Serbia and Kosovo. It must not be forgotten that the relations between Bulgaria and Serbia are burdened with open questions, although in recent years between Sofia and Belgrade established good-neighborly relations, more than half a century without precedent. Although it should not preclude re-actualization of the issue of the rights of the Bulgarian minority in Serbia.

The second problem is common to all countries of the Western Balkans: weaknesses in the judiciary, corruption in the higher echelons of power, lack of effective fight against organized crime. Because of that it's easily explained the sensitivity of the European Union to these problems and its intention not to allow import of the problems of the Western Balkans on its territory. That's why likely the EU accession of the new countries of the Balkan region will be seriously removed.

It requires immediately find satisfactory answers to at least two important questions:

First: Is there a way out of the worst crisis in the history of European integration?

Second: What should be the output?

We feel obliged to offer our answer, although we realize the huge risk of our forecasts failure and being charged of immodesty. First: Yes! There is an answer! But when meeting a mandatory requirement: categorical and real (not just declarative) wish of the applicants is to meet all pre-defined requirements and criteria to join the European structures. At the same time the EU member states also to confirm heir sincere willingness to accept the Western Balkans, to set new requirements unachievable and insurmountable barriers without changing previously established rules and requirements and to introduce new ones. 
Second: Because of the presence of these already open and contentious issues between the Western Balkans and especially due to the threat, applicant state to impede the next membership candidate country, the practice to receive individual countries can be unproductive and even counterproductive. Much more appropriate (at least at this point) looks receiving a package of all the countries of the Western Balkans.

\section{REFERENCES}

1) Fajon: Concern over Bosnia and Herzegovina, Western Balkans at a crossroad Liberation (Sarajevo), 31.10.2012.

2) Clinton requires reforms in the Balkans - Morning journal, 30.12.2012; http;//www.dw.de/клинтон-е-исфрустирана-од-босанските лидери/a-16343224

3) Hilary Clinton in Pristina: Independence of Kosovo undisputable -Politics

4) 31.10.2012.; http://www.nspm.rs/hronika/hilari-klinton-nezavisnostkosovanesporna-

5) Macedonia should receive a date for negotiations in December. Morning journal 24.10.2012.

6) Faion: Postpone of the negotiations bad for Macedonia and the region Morning journal - Utrinski vesnik, 06.11.2012.

7) Macedonia will start with the negotiations if accepts the advice of EU. Morning Journal 23.10.2012.

8) Zahariev Zahari . Where are you going Europe, Where are you going Balkans? 2012.

9) Gorgi Misajlovski, Nobel prize - Morning Journal 22.10.2012.

10) Documents. Progress Report on Serbia in 2012; European Commission; New Serbian Political Thought 18.Oktobar 2012.

11) Cekerac, M., Bosnian issue isn't a new condition Politics, 28. October, 2012.

12) Cpajak, Biljana. What will Hilary Clinton and Catherine Ashton offer?, Politics, October 28, 2012

13) Cerovina J., Topic of the day, Serbia, America and EU in the same duty October 31, 2012.

14) Misic M., Chronicle Hilary Clinton: Serbia can't join the EU without recognized borders and as long as there are security forces in Northern Kosovo Politics, October 3, 2012.

15) Cpajak, Biljana, What kind of messages brings the American-European duo, Politics. 31.10.2012.

16) Pesic, M., J. Cerovska, Srbija talks: Interpretation of Brussels Agreement Politics, 31.10.2012.

17) British MPs against Croatia's accession in the EU; Morning journal 07.11.2012.

18) Last Balkan mission- Hilary Clinton novilist.hr. October 31, 2012.; Hilary Clinton: Decrease bureaucracy and American investors will come in Croatia

1. 